\title{
Paleopathological and molecular study on two cases of ancient childhood leprosy from the Roman and Byzantine Empires
}

\section{With 10 figures in the text}

\section{Mauro Rubini $^{1^{*}}$, Yilmaz S. Erdal ${ }^{2}$, Mark Spigelman ${ }^{3,4}$, Paola Zaio ${ }^{1}$, Helen D. Donoghue ${ }^{3,5}$}

${ }^{1}$ Servizio di Antropologia S.B.A.L.,v. degli Stabilimenti 500019 Tivoli, Italy

${ }^{2}$ Department of Anthropology, Hacettepe University, 06800 Beytepe Ankara, Turkey

${ }^{3}$ Department of Infection, University College London, UK

${ }^{4}$ Department of Microbiology and Molecular Genetics, Hebrew University-Hadassah Medical School, Jerusalem, Israel

${ }^{5}$ The UCL Centre for the History of Medicine, University College London, UK

* e-mail antropologiasal@libero.it

This article has been accepted for publication and undergone full scientific peer review but has not been through the copyediting, typesetting, pagination and proofreading process which may lead to differences between this version and the Version of Record. Please cite this article as an 'Accepted Article', doi: 10.1002/oa.2242 


\section{Abstract}

This study is based on the palaeopathology of leprosy on human skeletal remains and the detection of ancient Mycobacterium leprae DNA. Two cases of childhood leprosy were recognised. The first case was in a Roman necropolis at Martellona (Rome, Central Italy), dated to the $2^{\text {nd }}-$ $3^{\text {rd }}$ century CE. The skeleton of a child aged $4-5$ years, from tomb 162 , is the youngest individual in Italy from this time period, with the clear rhino-maxillary syndrome and other bony changes indicative of leprosy. The second case from a burial at Kovuklukaya, in the Sinop region of Northern Turkey was from the $8^{\text {th }}-9^{\text {th }}$ century, during the Byzantine era. The endocranium of a 4-5 months old infant with new bone formation an indication of chronic inflammation - was positive for M. leprae DNA. Infant and childhood leprosy is uncommon today and there is a scarcity of information in the osteoarchaeological literature of leprosy in the past, especially in children. The significance of these cases is that it adds to an understanding of the history of the disease in the former Roman Empire. It is hoped that over time sufficient data can be obtained to understand the epidemiological dynamics and clinical evolution of leprosy from the ancient period until today.

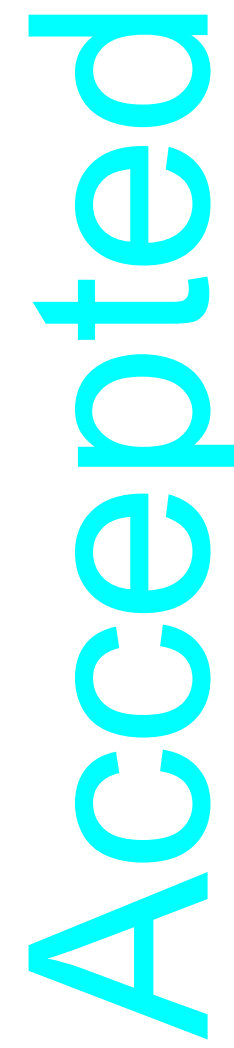

Key words $-2^{\text {nd }}-3^{\text {rd }}$ century CE; $8^{\text {th }}-9^{\text {th }}$ century CE; Byzantine period; Central Italy; Turkey; Leprosy; ancient DNA 


\section{Introduction}

Leprosy (or Hansen's disease) is a chronic infectious disease caused by an unculturable pathogen: Mycobacterium leprae, an acid-fast, rodshaped bacillus. Leprosy is rarely found today in Europe but is still a significant disease worldwide, principally in Southeast Asia, Africa and South America (Brazil) (World Health Organization, 2011). Primarily transmission occurs through droplet infection (Nunzi and Likey, 2005). The incubation period is very long, sometimes up to 20 years, before clinical signs and symptoms become apparent (Robbins and Cotran, 2002). Leprosy can affect all age groups, although it is often first observed before the age of 20 (Resnick, 2002). The disease primarily affects the peripheral nervous system, especially the extremities, and secondarily involves the skin, nasal tissues and, in the most severe forms, the bones (Nunzi and Likey, 2005). M. leprae is a highly infective bacterium with low pathogenicity; that is, its ability to induce clinical disease is low (Robbins and Cotran, 2002). The bacterium accumulates principally in the extremities of the body, where it resides within the macrophages and infects the Schwann cells of the peripheral nervous system. Lack of myelin production by infected Schwann cells, and their destruction by host-mediated immune reactions, leads to nerve damage, sensory loss and the disfiguration that are the characteristic signs of leprosy (Nunzi and Likey, 2005). The response to the disease is highly variable, and the genetic background and immune status of each infected person determine the type and severity of pathological change (Robbins and Cotran, 2002). In its most severe form, multibacillary (lepromatous) leprosy, both the skin lesions and the peripheral nerve damage become generalised and symmetrical in nature. Those with high immune status are more likely to develop paucibacillary (tuberculoid) leprosy, where only a small number of skin lesions develop and peripheral nerve damage 
is asymmetrical (Nunzi and Likey, 2005). When leprosy affects the skeleton, a number of specific and non-specific bony and osteoporotic changes occur during pathogenesis (Thappa et al., 1992). Specific bone changes are caused by invasion of the tissues by M. leprae, which is why facial changes are seen; secondary bone changes are a result of peripheral nerve involvement (hands, feet and lower leg bones) and lead to sensory nerve anaesthesia, trauma to the hands and feet because people cannot feel the trauma, ulceration of the feet and hands, then secondary infection of the bones of the hands and feet. There is also motor nerve damage (claw hands and feet) and autonomic nerve damage (absorption, remodelling etc.). Osteoporosis is caused by disuse and is a reduction of the bony mass normally mineralized. Histologically, it is caused by three factors: reduction of osteoblastic activity, rise of osteoclastic activity or both (simultaneous competition). In leprosy nerve damage and the consequent cessation of normal functional activity of the limb produces an imbalance in the osteoclastic/osteoblastic equilibrium in the bones with a rise of the osteoclastic activity (resorption of the bone) that leads to osteoporosis by disuse (Robbins and Cotran, 2002; Bennike et al. 2005). Thus osteoporosis may produce remodelling of the bone because of the collapse of the cortical tissue under the pressure of the muscles. It is believed that the activity of remodelling produces the characteristic pencilling shape of the hands and feet bones (Kulkarni and Mehta, 1983; Robbins and Cotran, 2002). The cranial features of leprosy, the so called facies-leprosa (Møller-Christensen, 1969) or rhinomaxillary syndrome (Andersen and Manchester, 1992), consist of the progressive erosion of the alveolar process of the maxilla with the loosening and ultimate loss of the central and lateral maxillary incisor teeth. There is an associated erosion of the anterior nasal spine leading to its ultimate loss. The margins of the pyriform aperture become eroded at their lower parts. Both 
the nasal and the oral surfaces of the palatine process of the maxilla exhibit inflammatory changes, and there may ultimately be perforation of the hard palate (Roberts and Manchester, 2005). These rhinomaxillary changes are inflammatory and are due specifically to the action of the leprosy bacillus (Robbins and Cotran, 2002, Nunzi and Likey, 2005).

The decline of leprosy in Western Europe and in the Mediterranean Basin is probably due to a complex web of factors: medical, environmental, social and legal (Rawcliffe, 2006, Rubini and Zaio, 2009a, b). Initially it was believed that with increased urbanisation, tuberculosis became more prevalent and that as both diseases are usually contracted at a very early age (Robbins and Cotran, 2002), the majority of individuals, mostly young children, would, as now, overcome the primary tubercle invasion, recover, and henceforth be immune to leprosy (Manchester, 1984, Lietman et al., 1997, Robbins and Cotran, 2002). It is recognised that the Bacillus-Calmette-Guérin (BCG) vaccine is effective against leprosy in $20-91 \%$ of cases (Merle et al. 2010), suggesting cross-immunity between the two diseases, so underlying leprosy infection gave cross-immunity and some degree of protection. An alternative scenario that may have increased in importance with greater population density and social deprivation is that a higher proportion of primary tuberculosis cases died from the condition, thereby causing the leprosy decline noted in Western Europe (Donoghue et al., 2005a). It is recognised that there is a close antigenic relationship between M. leprae and M. tuberculosis (Shinnick et al., 1987, Ravindra et al., 2010). It was once believed that the higher reproductive rate of tubercle bacilli as compared to lepra bacilli and degree of cross immunity within an individual would not allow both infections to occur simultaneously, but a careful study of the early clinical literature, and more recent molecular studies, show that this belief was 
erroneous (Hansen \& Looft 1895, Nigam et al. 1979, Kumar et al. 1982, Jayalakshmi et al. 1987, Glaziou et al. 1993, Rafi \& Feval 1995, Kumar et al., 2000; Donoghue et al. 2005a, Prasad et al., 2010). Furthermore, Donoghue et al. (2005a) suggested that the immunological changes seen in multibacillary leprosy together with the socioeconomic impact of the disease might have led to increased mortality due to tuberculosis that resulted in the decline of leprosy in Western Europe. Bony changes in leprosy were found mostly among the adult individuals in palaeopathology. Sub-adult individuals with leprosy, especially those of infants in ancient times are very few in number. The aim of this study is to investigate and discuss two sub-adult individuals with bone changes on the skull from Roman and Byzantine cemeteries with respect to diagnosis, the spread of infection among sub-adults and possible reasons for the development of skeletal lesions in such young individuals.

\section{Material and methods}

The first sample was found in a Roman cemetery near Rome. The Martellona necropolis is a large inhumation area situated along the Tiburtina Way (fig.1). At present there are 412 excavated graves. The cemetery was used continuously from the $6^{\text {th }}$ century BCE $-4^{\text {th }}$ century CE. All the Roman phases are represented: Republican and Imperial Age. The main funerary typology is the "cappuccina" tomb. Trench graves and chamber tombs are also present. The grave goods are poor and very rare, especially in the tombs of the last period. The site shows an economy substantially agricultural and very poor. In the tomb number 162 (code GM162) was found a skeletal sample of a child chronologically dated to the $2^{\text {nd }}-3^{\text {rd }}$ century CE (Imperial Age) according to coins and pottery. Furthermore two adult individuals buried near this tomb were dated with 
calibrated $\mathrm{C}^{14}$. The result was $1817 \pm 25$ years before present $(193 \pm 25$ $\mathrm{CE})$. The osteoarchaeological remains from Martellona are incomplete but quite well preserved. In the case of GM162 the condition of the bones is good especially when considering the fragility due to the young age. The skeleton is represented only by the cranium and mandible, left clavicle and first and second left ribs. The age at death was estimated according to the Ubelaker (1989) and Maglietta (2004) methods on the chronological development of the dentition and on the radiological analysis of the complete dentition. The screening of the traces of leprosy on the skeleton was performed according to the suggestions of MøllerChristensen (1967, 1969, 1978), Andersen and Manchester (1992) and Roberts and Manchester (2005).

Kovuklukaya is located $300 \mathrm{~m}$ northeast of Çulhalı village, $10 \mathrm{~km}$ from the town of Boyabat in Sinop province, northern Anatolia, Turkey (fig.2). The site was excavated during a highway construction. The western side of the mound was inhabited during the Late Chalcolithic and Early Bronze Age (Özcan et al., 2003; Dönmez, 2005; Erdal 2008). A Byzantine cemetery was located at the top of the mound, which measures approximately 70-80 m. Thirty-six human skeletons were unearthed in 25 simple rectangular pits and cist graves (Özcan et al., 2003; Erdal, 2004, 2008; Dönmez, 2005). There were no grave goods except a crucifix found with an adult male individual. Human skeletal remains were dated to $1175 \pm 35 \mathrm{BP}$ based on $\mathrm{C}^{14}$ dating by Dr Elisabetto Boaretto of the Weizmann Institute of Science Radiocarbon Dating Laboratory. The calibrated range of $\mathrm{C}^{14}$ is CE $770-9702 \sigma$ (95.4\% probability). This age range falls at the end of first millennium $\mathrm{CE}$, and agrees with archaeological data that also suggest the upper layer of Kovuklukaya is a small sized Byzantine cemetery (Erdal, 2008). There were 17 males, 15 
females and 4 sub-adults (Erdal, 2004). The excavated skeletal remains from Kovuklukaya were well preserved. Occlusal grooves of the anterior dentition, skeletal pathologies and other anthropological data suggest that Kovuklukaya people were engaged in yarn production, weaving, tree felling and animal husbandry (Erdal 2004, 2008). In addition to this information about daily activities, two males and one female skeleton showed pathognomonic characteristics of leprosy (Erdal, 2004). These individuals and also bones from other individuals with non-specific pathology were examined for the presence of $M$. leprae ancient DNA (aDNA) using specific PCR (Donoghue et al 2005a). One of the subadults, a four-five months old infant from the simple pit grave SK 9/1, showed porous bone formation on the inner surface of the occipital and frontal bones (Fig 2). The individual has almost all cranial and postcranial bones. Other bones are fairly well preserved except the periosteal surface of tibia and forearms, and metaphyseal ends of many long bones. The age at death of the Kovuklukaya individual was estimated by dental calcification and maximal femur length (Ubelaker 1989; Scheuer and Black 2000).

\section{Molecular examination}

The recommended protocols of aDNA work (O'Rourke et al., 2000) were followed, with separate rooms for different stages of the process. Thirty $\mathrm{mg}$ of bone scrapings were sampled from the outer edge of the porous bone formation on the inner surface of the occipital and frontal bones of the Kovuklukaya infant. These were crushed in a sterile pestle and mortar, transferred into a $9 \mathrm{ml}$ tube of NucliSens ${ }^{\circledR}$ (bioMérieux) lysis buffer containing $5 \mathrm{~mol}^{-1}$ guanidium thiocyanate. Tubes were vortex-mixed, placed on a rotator for 2 hours, then vortexmixed again, placed in a water bath and incubated at $56^{\circ} \mathrm{C}$ for 96 hours. 
Negative extraction controls were processed in parallel with the test sample. Each $9 \mathrm{ml}$ tube was boiled for 1 hour, vortex-mixed and allowed to cool. To complete the disruption of the bone scrapings and the resistant cell walls of any pathogenic mycobacteria (Taylor et al., 2006), the sample was then snap-frozen in liquid nitrogen and thawed in a $65^{\circ} \mathrm{C}$ water bath. This was repeated twice. The sample was spun at $5000 \mathrm{~g}$ for 15 mins at $5^{\circ} \mathrm{C}$ and the supernatant carefully removed into a clean, sterile tube. DNA was captured by mixing for 100 mins with $50 \mu 1$ silica suspension (NucliSens ${ }^{\circledR}$ ) and centrifugation. The silica pellet was washed once with wash buffer (NucliSens $\left.{ }^{\circledR}\right)$, twice with $70 \%(\mathrm{v} / \mathrm{v})$ ethanol $(-20$ $\left.{ }^{\circ} \mathrm{C}\right)$ and once with acetone $\left(-20^{\circ} \mathrm{C}\right)$. After drying in a heating block, DNA was eluted from the silica using $60 \mu$ elution buffer (NucliSens ${ }^{\circledR}$ ), aliquoted and used immediately or stored at $-20^{\circ} \mathrm{C}$.

\section{DNA amplification and detection}

M.leprae DNA was detected by targeting a specific region of the repetitive element RLEP (37 copies/cell). A two-tube nested PCR was used which gives an outer product of $129 \mathrm{bp}$ and a nested PCR product of 99 bp (Donoghue et al., 2001). A hot-start Taq polymerase was used to minimise non-specific primer and template binding. Negative DNA extraction and PCR controls were processed alongside the test sample. Detection of PCR product was by staining with ethidium bromide and visualising under ultraviolet light.

\section{Description of the skeletons}

\section{Martellona}

The individual GM162 is a child of $4-5$ years of age. The cranial skeleton shows changes localized in the region of the nasal and buccal mucosae. The alveolar process of the maxilla displays an intense and complete 
erosive activity in the anterior part with osteolysis in correspondence of both central and right lateral incisors while the alveolar area of the left lateral incisor is damaged post-mortem. The anterior nasal spine has been entirely resorbed (fig.3). There is a bilateral symmetrical resorption and remodelling of the normally sharply defined inferior margins of the nasal aperture. The lateral margins are smooth and thick in appearance. In particular the right margin of the nasal aperture is deformed and rounded. The left and right inferior nasal conchae are partially resorbed. In conjunction with the remodelling of the margins of the nasal aperture, the alterations of the intranasal structures have resulted in the appearance of a wide semi-empty cavity. In the left anterior part light post-mortem damage is also present. The regression of the inferior portion of the superior face can be seen clearly in the lateral view of the skull (fig.4). Furthermore the hard palate shows fine pitting and in the left side a perforation of probable chronic infective origin is present. The lesion is of sub-circular shape. Its measurements are as follows: length parallel to the medial palatine suture $3.8 \mathrm{~mm}$, breadth $3.6 \mathrm{~mm}$ (fig.5). The radiological aspect confirms the infectious process involving the bony tissue of the rhino-maxillary and palatine region (figs. 6 and 7). The absence of the post-cranial skeleton prevents any evaluation of the level of changes in the limbs.

\section{Kovuklukaya}

The Kovuklukaya individual is an infant aged 4-5 months. In contrast to the Martellona individual with pathognomonic characteristics of leprosy, the Kovuklukaya individual has no signs of any lesion on well-preserved bones except for the occipital and frontal bones. Here porous bone formation was observed on the inner surface of the occipital bone (fig. 8), 
especially on the internal occipital protuberantia or cruciform eminence and prevailing through transverse sulci and sagittal sulcus. Porous bone structure can also be observed on the inner surface of the parietal margins on the occipital. Moreover, along the side of the coronal suture, severe porous structure can be detected both on the inner and outer surfaces of the frontal. The porous structure and new bone formation are highly dense and sometimes look similar to a cribrotic structure (fig. 9). However, there was no sign of infection on the facial skeleton, other bones of the skull, teeth and also post-cranial bones.

\section{Differential analysis and molecular analysis results}

In a number of pathological conditions there may be considerable destruction of bone in the rhinomaxillary region (Ortner, 2003; Rubini and Zaio, 2009). These conditions include lupus vulgaris (tuberculosis of the facial skin and soft tissue), actinomycosis, fungal infections such as mucormycosis, and granulomatous diseases such as sarcoidosis and treponemal diseases. In children there is also another disease, noma, which can involve the bone in the rhinomaxillary region (Robbins and Cotran, 2002).

Lupus vulgaris is a chronic tubercular infection of the skin involving soft yellow swellings, ulcers and abscesses. It can also affect children (Robbins and Cotran, 2002). Long-standing tuberculosis of the facial skin and soft tissues can lead to the destruction of the nasal bones (Meng et al., 1942). However, in this pathology the anterior alveolar process is rarely affected (Møller-Christensen, 1967; Robbins and Cotran, 2002), which discounts lupus vulgaris as a diagnosis.

Actinomycosis produces effects on the cervicofacial area; bone involvement is rare. When affected, the mandible rather than the maxilla 
is more involved (Ortner 2003). This is not the case in the individual GM162.

Mucormycosis (phycomycosis) is a rare invasive fungal infection, which tends to affect people who have poorly controlled diabetes. It results in black, dead tissue in the nasal cavity and blocks the blood supply to the brain, leading to neurological symptoms, such as headaches and blindness (Ruoppi et al., 2001). Mucormycosis attacks the nasal cavity with involvement of the paranasal sinuses and their walls (Ortner, 2003). A diagnosis of a mucormycosis can be ruled out.

Sarcoidosis is a granulomatous disease of unknown aetiology. Like leprosy, it tends to affect the phalanges of the fingers and toes, causing lytic lesions and no reactive bone formation (Ortner, 2003; Robbins and Cotran, 2002). However, in the skull it causes mainly destruction of the nasal bones but rarely of the anterior nasal spine and never of the crest. Thus, we can exclude this disease as an explanation for the bony lesions in our Martellona specimen.

Destruction observed on the maxillo-palatal area can also be a symptom of tuberculosis. However, gross destruction of the facial skeleton and skull are extremely rare in tuberculosis (Rogers \& Waldron, 1989; Manchester, 1984; Ortner 2003). The lesion is largely destructive without gross evidence of repair in tuberculosis (Manchester, 1984, Ortner, 2003), whereas the destruction observed on the rhinomaxillary area of the Martellona specimen shows signs of a healing process.

In view of the reconsideration of the origin of treponemal disease in the Old World, this group of pathologies should also be discussed since, like leprosy, they can lead to the destruction of the nose and to bony changes in the lower limbs (Ortner 2003). Treponemal diseases 
include syphilis (venereal and endemic), yaws and pinta, which are granulomatous infections caused by spirochetes of the genus Treponema. Excluding pinta, which does not affect the bones, in the tertiary stage these diseases can involve the skeleton in about 3-5\% of yaws cases, 6$8 \%$ of bejel or endemic cases and $10-12 \%$ of venereal cases (Robbins and Cotran, 2002). They tend to be associated with inflammatory bony changes accompanied by extensive bone regeneration, often resulting in alteration of the bone morphology. These changes can be specific: necrosis as a surface depression that represents the foci of necrotic bone (gummatous lesions); or non-specific: periostitis, osteitis and osteoperiostitis (nongummatous lesions). In some cases destruction of the nasal-palatal area may occur (Ortner 2003; Erdal 2006). The last stage of yaws can be characterized by widespread bone, joint and soft tissue destruction, which may include extensive destruction of the bone and cartilage of the nose (rhinopharyngitis mutilans or 'gangosa'). Joints may stiffen, and chronic osteitis and periostitis can lead to bent leg bones (sabre tibiae). In bejel (endemic syphilis) periostitis of the leg bones is commonly seen. More rarely, bejel involves the skull, with gummas of the nose and soft palate developing in the last stage (Robbins and Cotran, 2002). The 'gangosa' condition may occur. The most commonly affected bones in venereal syphilis are (in order of importance) the tibia, frontal and parietal (with caries sicca on the outer tables), nasal-palatal region, clavicle, sternum, vertebrae, fibula, femur, humerus, radius and ulna (Ortner, 2003). Also the teeth can be involved, showing a screwdriver shape (Hutchinson teeth). No specific involvement of the feet is observed in this pathology. The tibia (with sabre-shaped deformity) and the skull are the most common bones afflicted during the tertiary stage of the disease. According to Ortner (2003), the calvarial lesions are the most specific diagnostic features. Although the nasal cavity is often enlarged, 
producing the characteristic "saddle nose", the nasal spine is usually spared (Rogers and Waldron, 1989). Furthermore, the anterior alveolar process is uncommon in yaws and syphilis (Møller-Christensen, $1967 \mathrm{p}$. 297). In children congenital syphilis may occur. This variant of syphilis shows Hutchinson's incisors that are typical of this condition, as are Mulberry molars (Robbins and Cotran, 2002; Erdal 2006). In the present case GM162, the pathogenic picture does not correspond to that of treponemal diseases because stallea scars or caries sicca, and dental stigmata of the congenital syphilis are not present.

Noma (derived from the Greek "nomein" meaning "to devour") is a devastating gangrenous disease which attacks children, quickly destroying their mouth, nose, and face, and which can prove fatal after just a few weeks (Robbins and Cotran, 2002). Noma, also known as cancrum oris, seems to start on the gum and extends outwards to the cheeks and lips. Without prompt treatment, mortality rates from this disease are as high as $70-90 \%$, with most deaths attributed to complications such as pneumonia, diarrhoea and septicaemia (Robbins and Cotran, 2002). Noma can involve the bone of the rhinomaxillary region, but only with asymmetrical expression while the nasal spine and hard palate are usually spared. Therefore, in the Martellona case we excluded this diagnosis. Given the expression and distribution of the changes in this first case, the most likely diagnosis is leprosy (MøllerChristensen, 1967, 1969, 1978; Andersen and Manchester, 1992, Roberts and Manchester, 2005). Important osteological changes are present in the rhinomaxillary region. The resorption of the anterior nasal spine, the enlargement and rounding of the piriform aperture, the cicatrisation of the lower margin of the nasal aperture and erosion of the alveolar margin accompanied by the loss of the front teeth shown in our case are the 
classic changes seen in leprosy referred to as facies leprosa (MøllerChristensen, 1967; Rogers and Waldron, 1989) but more appropriately in palaeopathology as rhinomaxillary syndrome (Andersen and Manchester, 1992, p.122). Furthermore the perforation of the hard palate is present. This last change is strongly pathognomonic in leprosy diagnosis (Roberts and Manchester, 2005; Nunzi and Likey, 2005). An initial examination of the Martellona sample for M. leprae DNA in the Jerusalem laboratory was unsuccessful (data not shown).

The pathological lesions detected on the child skeleton from Martellona are similar to the adult specimens from Kovuklukaya especially those of SK 20/1 and SK 24/1 (Erdal, 2004). However, there are no pathognomonic lesions observed on the individual SK 9/1. Only the occipital and frontal have reactive new bone formation on the endocranial surfaces. Møller-Christensen (1961) referred to the lesions as cribra cranii interna and regarded them as part of the same process contributing to the orbital lesions, which were considered inflammatory in origin. Reactive new bone on the endocranial surface of the skull is commonly found on the occipital bone, outlining the cruciate eminence (Lewis, 2004), while new bone on the original cortical surface expands around meningeal vessels. Lewis (2004) suggests that the majority of cases in the youngest age category ( $0-0.5$ years) are probably nonpathological in origin, and the result of rapid growth in that area. She also concludes that the aetiology of these lesions should be referred to as non-specific indicators of haemorrhage or infections (Lewis, 2004). The presence of new bone formation on the endocranial surface in the SK 9/1 infant may be related to bacterial or viral infections, or non-infectious conditions such as tumours and haemorrhage (Schultz, 2001; Roberts and Manchester, 2005). There is no other pathognomonic lesion of leprosy 
found on SK 9/1. However, the bone scrapings from the inner surface of the occipital of SK 9/1 were positive for M. leprae DNA using nested PCR (fig. 10). This lesion on the internal surface of the occipital and frontal bones of SK 9/1 may, therefore, be a non-specific indicator of bacterial inflammation due to leprosy.

\section{Discussion}

Today the frequency of occurrence of leprosy in children is an important epidemiological parameter for determining the rate of transmission of disease (Burman et al., 2003). The source of infection is usually an infectious case in the family, particularly for the pre-school age group. According to Melson et al. (1982) 25-50\% of children born into families with multibacillary leprosy develop clinical signs of the disease before the age of five years. In many cases, leprosy heals spontaneously but may re-occur when the child is adult. Clinical features of leprosy in children may sometimes be confusing. Sensory testing is difficult to perform and slit-skin smears (SSS) are usually negative (Prasad, 1998).

Histopathology may be unrewarding in early tuberculoid and indeterminate leprosy and there may be a marked disparity between the clinical and histopathological features. It has been suggested that the clinical spectrum of leprosy according the Ridley-Jopling scheme (Ridley and Jopling, 1966), is incomplete in the 0-14 year age group since most of the cases are indeterminate (I), tuberculoid (TT), borderline tuberculoid (BT), or mid-borderline (BB) and very few are borderline lepromatous (BL) or lepromatous (LL), especially in children under 5-6 years of age (Nunzi and Likey, 2005). Another variant present in children is nodular leprosy (NL). NL is a benign clinical variant of the paucibacillary leprosy that affects breastfeeding infants and children that 
remain in a highly infected environment (Fakhouri et al, 2003). The lesions resolve with complete healing and NL has been considered a manifestation of allergy and congenital immunity to M. leprae (Fakhouri et al, 2003).

The bone changes on the Martellona sample indicate a well-developed phase of leprosy. The M. leprae has clearly proceeded from the infected mucosae to the cartilaginous tissue and finally to the bony tissue. Here it has produced an intense osteoclastic activity with absence of any bony repair. This clinical condition is normally only present today in untreated cases. The introduction of multi-drug therapy is relatively recent (1982) and in ancient times the disease carried out its natural course. This situation allows evaluation of the effective development of the leprosy and the physiological reaction of the human body and the cell mediated immune response (CMI). In our first case the severity of the clinical condition shows a high level of expression of the disease. The relation between the nature and severity of the bony changes and the young age suggest a quick and serious development of the disease (Schwarz and McDonald, 2004). Today there are no literature or hospital reports on children under 4-5 years with lepromatous leprosy that show such an involvement of the bones, even in underdeveloped countries where the medical control is difficult (WHO, 2011). Recent studies reveal maximum incidence rates among children aged 10-14 years (Selvasekar et al., 1999). Given the long incubation period, it can be inferred that younger children are indeed at greater risk. Today childhood leprosy is mostly seen in the age group of 4-14 years (Vara, 2006), although leprosy has also been described in 91 infants (Brubaker et al., 1985). In the Martellona case severe changes of the bones of the face are present. The perforation of the hard palate and the destruction of the nasal bones have 
produced a visible deformity in the rhinomaxillary portion. This condition displays an advanced phase of the disease, indicating a low cell mediated immune reaction and high bacteriological load, typical of the multibacillary form (Nunzi and Likey, 2005).

Leprosy in infancy has received little attention in palaeopathology in recent years but has been described (Lewis, 2002). One reason of this is that a significant proportion of the infected infants die of other causes. In addition, the pathological changes are likely to be observed later in childhood due to the length of the incubation period, giving difficulty in diagnosing leprosy in infant specimens based solely on gross skeletal morphology such as the rhinomaxillary syndrome. This is the probable explanation for the absence of pathognomonic lesions of leprosy in the Kovuklukaya specimen. Porous structures on the inner surface of the skull are not themselves pathognomonic lesions of leprosy. However, similar osseous lesions were found in the nasal cavities, hard palates, alveolar process and the oral surfaces of the palatine process of the maxillae, on three adult individual skeletons from the same site: two males and one female. On SK 20/1 and SK 24/1, complete destruction (disappearance) of the anterior nasal spines is observed. The narrowing of the pre-maxillary area related to the infections on the anterior nasal spines has occurred on these two individuals, plus symmetrical resorption and smooth remodeling of the margins of the nasal apertures (rounding and widening of the nasal aperture). On the border of the nasal aperture, the inner surface of the frontal process of the maxillae and both oral and nasal surfaces of the hard palates have active porosity resulting from inflammation (Erdal, 2004). Most of the intranasal bones such as the vomer and the concha nasalis inferior have been destroyed due to infection while nasal apertures have enlarged and rounded, giving the 
appearance of a wide semi-empty cavity. In SK 20/1, the upper central and lateral incisors have been lost before death due to an infection in the pre-maxillary area. Therefore, lesions on facial skeletons of these two individuals have the typical characteristics of rhinomaxillary syndrome. Erosive lesions have developed near the palatine suture in the mid-portion of the palate on the oral surface. A perforation about $8 \times 13 \mathrm{~mm}$ in diameter is present on the hard palate of SK 24/1. In addition, there is a porous lesion on the hard palate of the individual registered as SK11/2 (Erdal, 2004).

On the same skeletons, periostitis has developed on the anterior surfaces of the distal parts of the tibiae and fibulae. Infection is also present on the metatarsals (SK 20/1). Partial paralysis of the foot bone may have deformed the foot, and extra joint surfaces (palmar grooves) have developed on the palmar and planter surfaces of fingers (Erdal, 2004). These pathological changes on the anterior nasal spine, intranasal structure, margins of the nasal aperture, hard palate, and metatarsal bones, tibiae and fibulae observed on three skeletons discovered in Kovuklukaya suggest that pathogens were present during the Byzantine era in the site. Together with the pathognomonic changes typical of leprosy, aDNA studies on Kovuklukaya individuals (Donoghue, 2008; Taylor and Donoghue, 2011) have proved that M. leprae was present in the settlement. It is well known that transmission of the organism from an infected individual to another easily occurs via aerosols and that leprosy affects family members (Nunzi and Massone, 2009). Therefore, the most probable explanation for the palaeopathological features in both the Martellona and Kovuklukaya individuals, is that they were infected by a member of their family via the respiratory route or skin contact. 
It has also been reported that the leprosy is present in utero, in infants under one year of age, and therefore there is a haematogenous spread of the infection (Lewis 2002). Pregnant woman with paucibacillary or borderline leprosy have been shown to revert to multibacillary leprosy after conception. Acid-fast bacilli have been shown in the placenta and cord blood, suggesting that congenital leprosy can occur (Donoghue, 2008). It has also been suggested that M. leprae may be transmitted to the foetus via sperm (Lewis 2002). The presence of M. leprae in breast milk suggests a potential gastrointestinal route of infection (Lewis 2002). Therefore, it is possible that both the Martellona and Kovuklukaya individuals were infected in utero or during the early infantile period. This could be an explanation for the severity of the changes in the Martonella individual GM162, and the appearance of chronic inflammation in the four-five months old infant from Kovuklukaya.

The failure to demonstrate $M$. leprae DNA in the Martellona case may be due to several reasons, such as the small quantity of bony sample, the absence or uneven distribution of $M$. leprae DNA in the specimen, or poor DNA preservation. However, an important factor is likely to be that the disease is present in such an advanced phase. It is the early cases of ancient leprosy with non-specific pathological changes that often demonstrate good recovery of $M$. leprae DNA, such as the samples examined by Donoghue et al. (2002) and our present second case from Kovuklukaya. The destruction of the nasal bones and the perforation of the hard palate in the Martellona specimen show the presence of leprosy for a long period. In consideration of the young age of the subject, this case of primary leprosy may have been congenital or contracted from an infected mother or possibly another family member, immediately after the birth. This could explain the advanced phase of disease (Schwarz and 
Mcdonald, 2004). An important observation is that today the studies on leprosy sufferers in the absence of drug therapy show changes in the rhinomaxillary skeletal region only after about $7-10$ years from the likely date of infection (Schwarz and Mcdonald, 2004). Therefore, this is the most likely reason why today children under 14 years of age with leprosy do not show significant changes in the facial bones (Prasad et al. 2004).

Another possibility for the early onset of pathology is that in the past M. leprae was more aggressive than today. Monot et al. (2005), in a phylogeographic study on leprosy, genotyped 175 strains of M. leprae from 21 different geographic origins, but of 64 possible permutations only four phylogenetic groups based on single nucleotide polymorphisms (SNPs) occurred. A close relationship was established between the geographical origin of the strain and its genotype, giving a first impression of how leprosy may have disseminated around the globe as humans migrated. The European phylogenetic group is SNP-type 3. This shows five subtypes (I-M) in extant populations and a few well-preserved samples of extinct strains from the first millennium CE were identified as subtypes I, K, L and M (Monot et al., 2009). This demonstrates a continuity of $M$. leprae type 3 and its subtypes during the last 2,000 years in Europe. Parallel to this, Gomez-Valero et al. (2007) demonstrated in a phylogenomic study that during the reductive evolution of $M$. leprae, 1537 of 2977 ancestral genes were lost, among which were 177 previously unknown pseudogenes. It is clear that a massive gene inactivation took place relatively recently in the M.leprae lineage, leading to the loss of hundreds of ancestral genes. A large proportion of the pseudogene nucleotide content ( $\sim 89 \%$ ) remains in the genome, which allows its characterization and dating. The position of the genes that were lost in the presumed ancestral organism reveals that the process of 
function loss and degradation mainly took place through a gene-to-gene inactivation process, followed by the gradual loss of DNA. The massive genome reduction, through many nearly simultaneous pseudogenization events, has led to a highly specialized pathogen (Gomez-Valero et al., 2007) indicated by the presence of leprosy today in only humans and some species of American armadillos. This work indicates that the type and subtypes of leprosy are the same in the past as today. Indeed, the adult female case of leprosy from Kovuklukaya was sub-genotyped and found to be of type $3 \mathrm{~K}$, which is the same sub-genotype found in modern Turkey and Iran (Monot et al 2009). Consequently, a possible different and greater aggressiveness of the disease in the past is likely either because of the low immunological status of the host individuals, or because of an as-yet undetected bacteriological difference in ancient compared with modern $M$. leprae. This last point could be a result of the co-evolution of M.leprae with its human host, resulting in a less aggressive infection over time (Gomez de Valero et al., 2007; Monot et al., 2009).

The cases in this study have enriched the scanty osteoarchaeological documentation of leprosy in childhood and infancy during the Roman and Byzantine period, and contributed to reducing the discrepancy between the historical and biological evidence. At this moment the case of Martellona is the first case in Italy (and possibly in the world) of a child under 5 years of age with a clear rhinomaxillary syndrome. Other cases of children and adolescents with rhinomaxillary syndrome have been reported in the literature, but not under 5 years. For example, a skull of an 8-9 year old child of unknown provenance is held in the skeletal collection at the University of Bradford (Lewis, 2002). Brothwell (1958) reported a skull of a child aged between 14-16 years 
from Scarborough Castle with rhinomaxillary syndrome. MøllerChristensen (1961) revealed that three young children aged between 8-10 years from St. Jorgen's Hospital in Næstved show changes typical of rhinomaxillary syndrome. He also published (1978) evidence for rhinomaxillary syndrome in 12 juveniles. Anderson (1996) described 11 cases of leprosy in sub adults from the later Medieval site of Sr. John Timberhill in Norwich. Recently Kjellström (2010) described a case of rhinomaxillary syndrome in a child of 11-12 years from Sigtuna (Sweden). The case from Kovuklukaya displays no pathognomonic bone changes for leprosy but the palaeopathology is consistent with a chronic inflammatory response and specific PCR is positive for M. leprae DNA (Donoghue et al., 2005b). We believe that this is the youngest individual in the world known to have had leprosy in the past. In sum, this study suggests that skeletal changes on young children must be analyzed in detail and aDNA analysis should be applied on sub adult individuals, especially those who have non-specific infectious lesions, who are in populations with adult individuals with pathognomonic lesions of leprosy.

\section{Conclusions.}

The first case from $2^{\text {nd }}-3^{\text {rd }}$ century CE Italy shows strong palaeopathological evidence of advanced leprosy and is the first recognized case of rhinomaxillary syndrome in a child under 5 years. The lack of DNA confirmation is consistent with other findings that molecular results are more likely in the early stages of disease. The second case, from the $8^{\text {th }}-9^{\text {th }}$ century CE Byzantine Empire in modern day Turkey, with the non-specific inflammatory changes and confirmation by aDNA of M. leprae, is the youngest individual known in the world to have had 
leprosy in the past. Overall, the results of this study suggest that skeletal changes on young children must be analyzed in detail and aDNA analysis should be applied on sub adult individuals, especially on those who have non-specific infectious lesions in populations with adult individuals who have pathognomonic lesions of leprosy.

\section{Acknowledgements}

Mauro Rubini and Paola Zaio would like to thank: Professor Charlotte Roberts, Department of Archaeology Durham University, and Dr Mary Lewis, Department of Archaeology School of Human and Environmental Sciences University of Reading, for the precious information on childhood leprosy in the past; Vittorio Cerroni, Scientific Technical Assistant of the Anthropology Laboratory of the S.B.A.L., for the graphic creations and figures.

This study was made possible by a grant of the Ministero per i Beni e le Attività Culturali d'Italia.

\section{References}

Anderson, S., 1996. Leprosy in a Medieval Churchyard in Norwich, in: Anderson, S., (Ed.), Proceedings from the First Annual Meeting of the Osteoarchaeology Research Group. Oxford, Oxbow Books, 31-37.

Andersen, J.G., Manchester, K., 1992. The rhinomaxillary syndrome in leprosy: a clinical, radiological and palaeopathological study.

International Journal of Osteoarchaeology 2, 121-129.

Bennike, P., Lewis, M.E., Schultkowski, H., Valentin, F., 2005. Comparison of child morbidity in two contrasting Medieval cemeteries 
from Denmark. American Journal of Physical Anthropology 128, 734746.

Brothwell, D.R., 1958. Evidence of leprosy in British archaeological material. Medical History 2, 287-291.

Brubakar ,M.L., Meyers, W.M., Bourland J., 1985. Leprosy in children one year of age and under. International Journal of Leprosy 53, 517-523.

Burman, K.D., Rijall, A., Agrawal, S., 2003. Childhood leprosy in eastern Nepal: a hospital based study. Indian Journal of Leprosy 75, 47-52.

Donoghue, H.D., 2008. Molecular paleopathology of human infectious disease. Chapter 8 in: Pinhasi, R., Mays, S. (Eds.), Advances in human paleopathology. Wiley \& Sons Ltd, Leicester, 147-176.

Donoghue,H.D., Holton,J., Spigelman,M., (2001). PCR primers that can detect low levels of Mycobacterium leprae DNA. Journal of Medical Microbiology 50, 177-182.

Donoghue,H.D., Gladykowska-Rzeczycka,J., Marcsik,A., Holton,J., Spigelman,M. (2002). Mycobacterium leprae in archaeological samples. in Roberts,C.A., Lewis,M.E., Manchester,K. (ed.) The Past and Present of Leprosy: Archaeological, historical, palaeopathological and clinical approaches. British Archaeological Reports International Series, 1054, Oxford: Archaeopress, 271-285.

Donoghue, H.D., Marcsik, A., Matheson, C., Vernon, K., Nuorala, E., Molto, J.E., Greenblatt, C.L., Spigelman, M., 2005a. Co-infection of Mycobacterium tuberculosis and Mycobacterium leprae in human archaeological samples: a possible explanation for the historical decline of leprosy. Proceedings of the Royal Society of London Series B 272, 389-394.

Donoghue, H.D., Erdal, Y.S., Pinhasi, R., Spigelman, M., 2005b. A possible case of congenital leprosy in a 5-month-old child from Byzantium Age in Turkey, in: 26th Annual Congress of the European Society of Mycobacteriology. 26-29 June 2005, Istanbul, Turkey.

Dönmez, Ş., 2005. Boyabat-Kovuklukaya: A Bronze Age settlement in the Central Black Sea region, Turkey. Ancient Near Eastern Studies 41: $36-82$. 
Erdal, Y.S., 2004. Health status of the Kovuklukaya (Boyabat/Sinop) people and its relations with their lifestyle. Istanbul Üniversitesi Edebiyat Fakültesi Anadolu Arastirmalari 17: 169-196. (in Turkish)

Erdal, Y.S., 2006. A pre-Columbian case of congenital syphilis from Anatolia. International Journal of Osteoarchaeology 16:16-33.

Erdal, Y.S., 2008. Occlusal grooves in anterior dentition among Kovuklukaya inhabitants (Sinop, Northern Anatolia, 10th century AD). International Journal of Osteoarchaeology 18:152-166.

Fakhouri, R., Sotto, M.N., Manini, M.I.P., Margarido, L.C., 2003. Nodular leprosy of childhood and tuberculoid leprosy: a comparative morphologic immunopathologic and quantitative study of skin tissue reaction. International Journal of Leprosy \& Other Mycobacterial Diseases 71, 218-226.

Glaziou, P., Cartel, J. L., Moulia-Pelat, J. P., Ngoc, L. N., Chanteau, S., 1993. Tuberculosis in leprosy patients detected between 1902 and 1991 in French Polynesia. International Journal of Leprosy \& Other Mycobacterial Diseases 61, 199-204.

Gómez-Valero, L., Rocha, E.P.C., Latorre, A., Silva, F.J., 2007.

Reconstructing the ancestor of Mycobacterium leprae: The dynamics of gene loss and genome reduction. Genome Research 17, 1178-1185.

Hansen, G. A., Looft, C., 1895. Leprosy: in its clinical and pathological aspects. Bristol: John Wright \& Co. (Reprinted 1973).

Jayalakshmi, P., Looi, L. M., Lim, K. J., Rajogopalan, K., 1987. Autopsy findings in 35 cases of leprosy in Malaysia. International Journal of Leprosy \& Other Mycobacterial Diseases 55, 510-514.

Kjellström, A., 2010. Possible cases of leprosy and tuberculosis in Medieval Sigtuna, Sweden. International Journal of Osteoarchaeology DOI:0.1002/oa.1204

Kulkarni, V.N., Mehta, J.M., 1983. Tarsal disintegration (T.D.) in leprosy. Leprosy in India 55, 338-370

Kumar, B., Kaur, S., Kataria, S., Roy, S.N., 1982. Concomitant occurrence of leprosy and tuberculosis - a clinical, bacteriological and radiological evaluation. Leprosy in India 54, 671-6. 
Kumar, B., Rani, R., Kaur, L., 2000. Childhood leprosy in Chandigarh: clinico histopathological correlation. International Journal of Leprosy \& Other Mycobacterial Diseases 68, 330-31.

Lewis, M.E., 2002. Infant and childhood leprosy: present and past. In: Roberts, C.A., Lewis, M.E., Manchester, K. (Eds.), The past and present of leprosy: Archaeological, historical, palaeopathological and clinical approaches. British Archaeological Reports International Series, 1054, Oxford, 163-70.

Lewis, M.E., 2004. Endocranial lesions in non-adult skeletons: understanding their aetiology. International Journal of Osteoarchaeology 14:82-97.

Lietman, T,, Porco, T., Blower, S., 1997. Leprosy and tuberculosis: the epidemiological consequences of cross-immunity. American Journal of Public Health 87,1923-1927.

Maglietta, D., 2004. Valori e dati clinici utili in Pediatria. Carlo Erba, Firenze.

Manchester, K., 1984. Tuberculosis and leprosy in antiquity an interpretation. Medical History 28, 162-173.

Melson, R., Harboe, M., Duncan, M.E., 1982. IgA, IgM and IgA anti-M. leprae antibodies in babies of leprosy mothers during the first 2 years of life. Clinical Experimental Immunology 49, 532-542.

Meng, C.M., Wu, Y.K., Peiping, C.B., 1942. Tuberculosis of the flat bones of the vault of the skull. Journal of Bone \& Joint Surgery (Br) 24, 341-353.

Merle, C.S.C., Cunha, S.S., Rodrigues, L.C., 2010. BCG vaccination and leprosy protection: review of current evidence and status of BCG in leprosy control. Expert Review of Vaccines 9, 209-222

Møller-Christensen, V., 1961. Bone changes in leprosy. Copenhagen, Munksgaard.

Møller-Christensen, V., 1967. Evidence of leprosy in earlier people in: Brothwell, D., Sandison, A.T. (eds), Disease in Antiquity. A Survey of Diseases, Injuries and Surgery. Charles C. Thomas, Springfield, 295306. 
Møller-Christensen, V., 1969. Provisional results of the examination of the whole Naestved leprosy hospital churchyard-ab. 1250-1550 A.D. Nordisk Medicin-Historisk ärsbok 29-41.

Møller-Christensen, V., 1978. Leprosy changes of the skull. Odense, University Press, Odense.

Monot, M., Honoré, N., Garnier, T., Araoz, R., Coppèe, J.Y., Lacroix, C., Sow, S., Spencer, J.S., Truman, R.W., Williams, D.L., Gelber, R., Virmond, M., Flageul, B., Cho, S.N., JI, B., Paniz-Mondolfi, A., Convit, J., Young, S., Fine, P.E., Rasolofo, V., Brennan, P.J., Cole, S.T., 2005. On the origin of leprosy. Science 308, 1040-1042.

Monot, M., Honoré, N., Garnier, T., Zidane, N., Sherafi, D., PanizMondolfi, A., Matsuoka, M., Taylor, G.M., Donoghue, H.D., Bouwman, A., Mays, S., Watson, C., Lockwood, D., Khamispour, A., Dowlati, Y., Jianping, S., Rea, T.H., Vera-Cabrera, L., Stefani, M.M., Banu, S., Macdonald, M., Sapkota, B.R., Spencer, J.S., Thomas, J., Harshman, K., Singh, P., Busso, P., Gattiker, A., Routgemont, J., Brennan, P.J., Cole, S.T. 2009. Comparative genomic and phylogeagraphic analysis of Mycobacterium leprae. Nature 41, 12: 1282-1289.

Nigam, P., Dubey, A. L., Dayal, S. G., Goyal, B. M., Saxena, H. N., Samuel, K. C., 1979. The association of leprosy and pulmonary tuberculosis. Leprosy in India 51, 65-73.

Nunzi, E., Likey, D.L. 2005. Manuale di Leprologia. OCSI, Bologna.

Nunzi, E., Massone, C., 2009. Note di Leprologia. AIFO Press, Bologna

O'Rourke, D. H., Hayes, M. G., Carlyle, S. W., 2000. Ancient DNA studies in physical anthropology. Annual Review of Anthropology 29, 217-242.

Ortner, D.J., 2003. Identification of Pathological Conditions in Human Skeletal Remains (2nd edn). Academic Press: Amsterdam.

Özcan, M., Dereli F. and Dönmez Ş. 2003. Kovuklukaya kurtarma kazısı. Türk Eskiçă̆ Bilimleri Enstitüsü, Haberler 15:21-22.

Prasad, P.V., 1998. Childhood leprosy in rural hospital. Indian Journal of Pediatrics 65, 751-754.

Prasad, S., Kumarasinghe, W., Kumarasinghe, M.P., Amarasinghe, U.T.P., 2004. Tap sign in tuberculoid and borderline tuberculoid leprosy. 
International Journal of Leprosy \& Other Mycobacterial Diseases 72, 291-295.

Prasad, R, Verma, S.K., Singh, R., 2010. Concomittant pulmonary tuberculosis and borderline leprosy with type-II lepra reaction in single patient. Lung India 27, 19-23.

Rafi, A., Feval, F., 1995. PCR to detect Mycobacterium tuberculosis DNA in sputum samples from treated leprosy patients with putative tuberculosis. Southeast Asian Journal of Tropical Medicine \& Public Health 26, 253-257.

Ravindra, K., Sugareddy, Ramachander, T., 2010. Coexistence of borderline tuberculoid Hansen's disease with tuberculosis verrucosa cutis in a child - a rare case. Indian Journal of Leprosy 82, 91-93.

Rawcliffe, C., 2006. Leprosy in Medieval England, Boydell Press, Woodbridge.

Resnick, D., 2002. Osteomyelitis, septic arthritis, and soft tissue infection: organisms. In: Diagnosis of Bone and Joint Disorders (4th edn), Resnick D (ed.). W.B. Saunders Co.: Philadelphia; Vol. 3, 25102624.

Ridley, D.S., Jopling, W.H., 1966. Classification of leprosy according to immunity, a five-group system. International Journal of Leprosy 34, 255273.

Robbins, S.L., Cotran, R.S., 2002. Pathologic Basis of Disease, W.B. Saunders Company, Philadelphia.

Roberts, C.A., Manchester, K., 2005. The archaeology of disease. $3^{\text {rd }}$ ed., Sutton Publishing, Gloucester.

Rogers, J., Waldron, T., 1989. Infections in palaeopathology: the basis of classification according to most probable cause. Journal of Archaeological Science 16, 611-625.

Rubini, M., Zaio, P., 2009a. Il sito dei "segnati” da Dio: Palombara Sabina. In Ghini G. (Ed), Sesto Incontro di Studi sul lazio e Sabina, Roma 4-6 marzo, 2009, Atti del Convegno 6, 101-104.

Rubini, M., Zaio, P., 2009b. Lepromatous leprosy in an early mediaeval cemetery in Central Italy (Morrione, Campochiaro, Molise, 6th -7th century AD). Journal of Archeological Science 36, 2771-2779 
Ruoppi, P., Dietzi, A., Nikanne, E., Seppaè, J., Markkanen, H., Nuutinen, J., 2001. Paranasal sinus mucormycosis: a report of two cases. Acta Otolaryngologica 121, 948-952.

Scheuer,L., Black S. 2000. Developmental Juvenile Osteology. Academic Press, San Diago.

Schultz, M. 2001. Paleohistopathology of bone: A new approach to the study of ancient diseases. Yearbook of Physical Anthropology 44:106147.

Schwarz, R.J., Macdonald, M., 2004. A rational approach to nasal reconstruction in leprosy. Plastic and Reconstructive Surgery 114, 876882.

Selvasekar, A., Joseph, G., Kurian, N., Manimozui, N., Iesudasan, K., Rao, P.S.S., 1999. Childhood leprosy in a endemic area. Leprosy Review $70,21-27$.

Shinnick, T.M., Sweetser, D., Thole, J., 1987. The etiologic agents of leprosy and tuberculosis share an immunoreactive protein antigen with the vaccine strain Mycobacterium bovis BCG. Infection and Immunity 55, 1932-1935.

Taylor, G.M., Watson, C.L., Lockwood, D.N.J., Mays, S.A., 2006. Variable nucleotide tandem repeat (VNTR) typing of two cases of lepromatous leprosy from the archaeological record. Journal of Archaeological Science 33, 1569-1579.

Taylor, GM., and Donoghue, H.D. 2011. Multiple loci variable number tandem repeat (VNTR) analysis (MLVA) of Mycobacterium leprae isolates amplified from European archaeological human remains with lepromatous leprosy. Microbes and Infection 13, 923-929.

Thappa, D.M., Sharma, V.K., Kaur, S., Suri, S., 1992. Radiological changes

in hands and feet in disabled leprosy patients: a clinical-radiological correlation. Indian Journal of Leprosy 64, 58-66.

Ubelaker, D.H., 1989. Human skeletal remains: excavation, analysis, interpretation. Manuals on Archaeology. 2, Smithsonian Institute, Taraxacum, Washington. 
Vara, N., 2006. Profile of new cases of childhood leprosy in a hospital setting. Indian Journal of Leprosy 78, 17-22.

WHO. 2011. Global strategy for the prevention of leprosy.

http://www.who.int/lep/strategy/en/ (accessed 7th October 2011) 

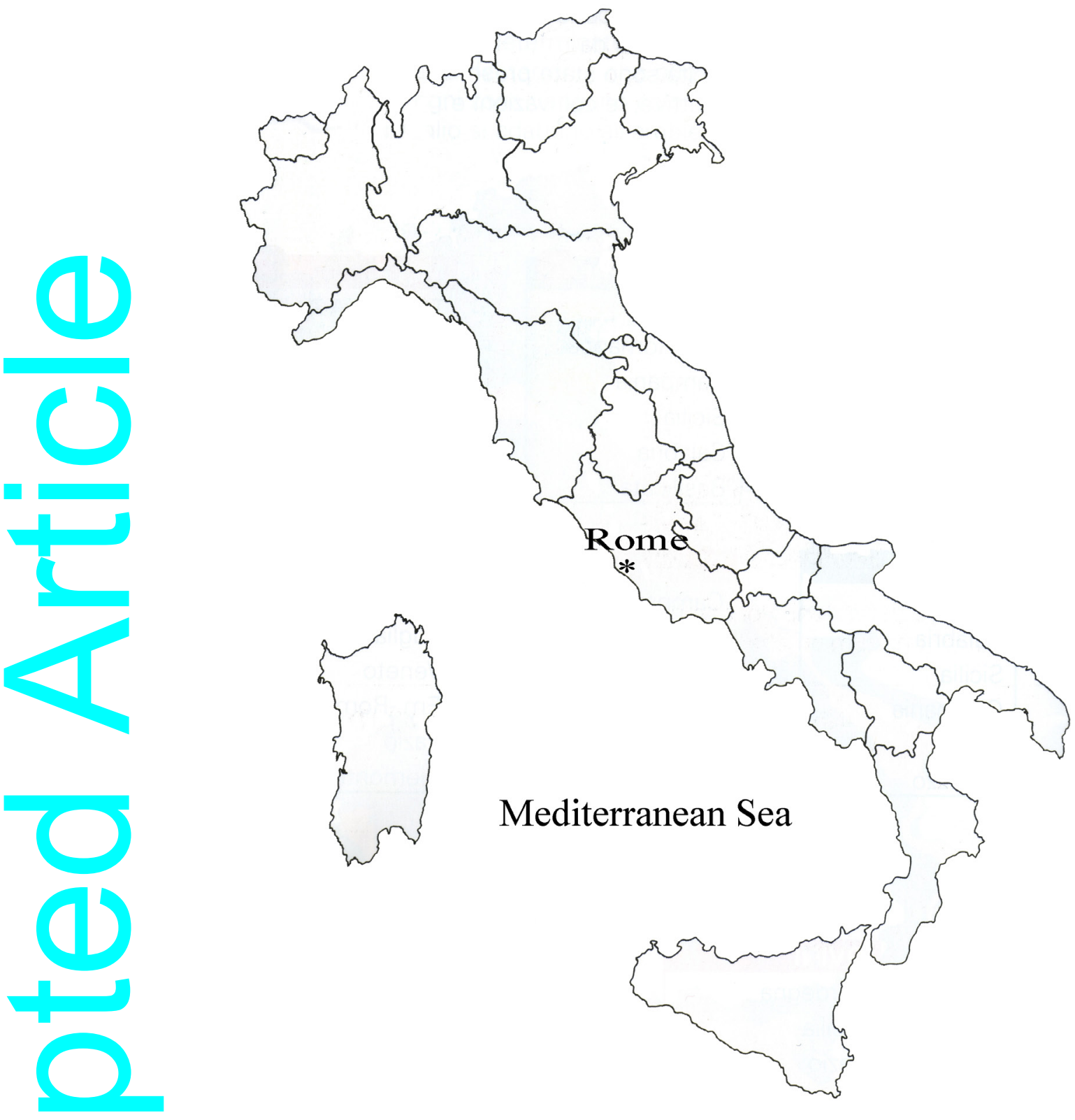

Figure 1 - Geographic location of Martellona 


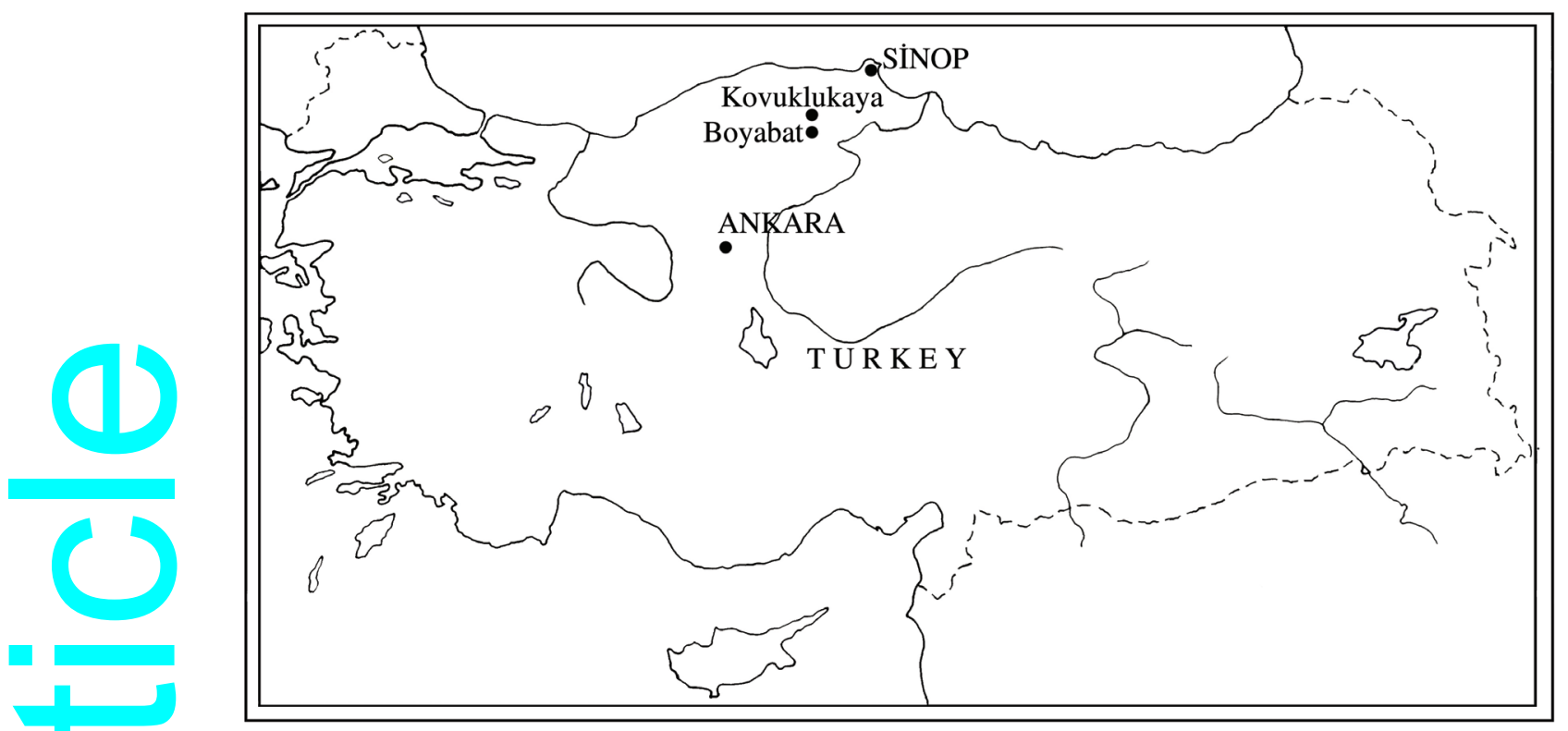

Figure 2 - Geographic location of Kovlukukaya 

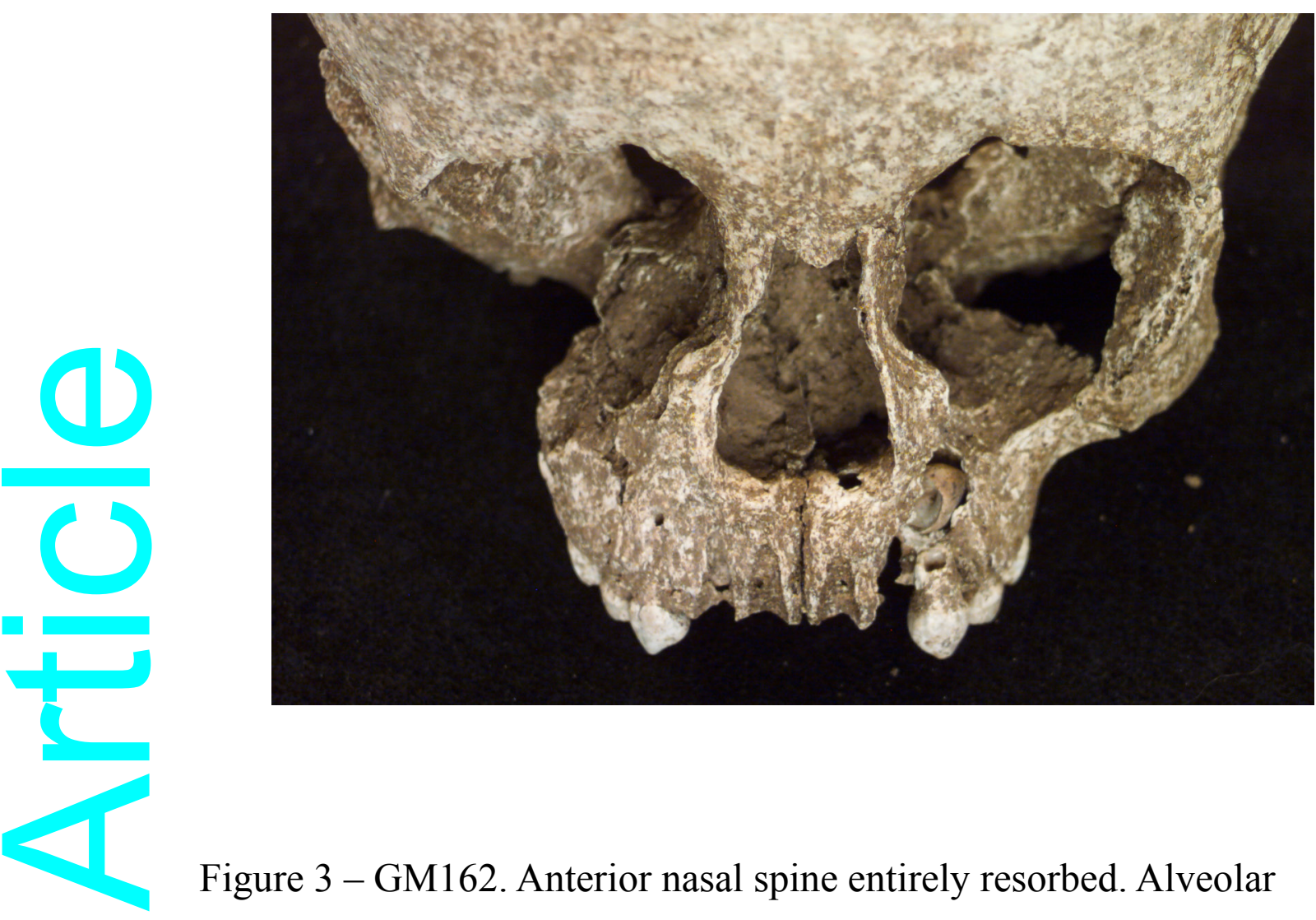

Figure 3-GM162. Anterior nasal spine entirely resorbed. Alveolar process of the maxilla with intense and complete erosive activity in the anterior part and osteolysis in correspondence of the both central and right lateral incisors 

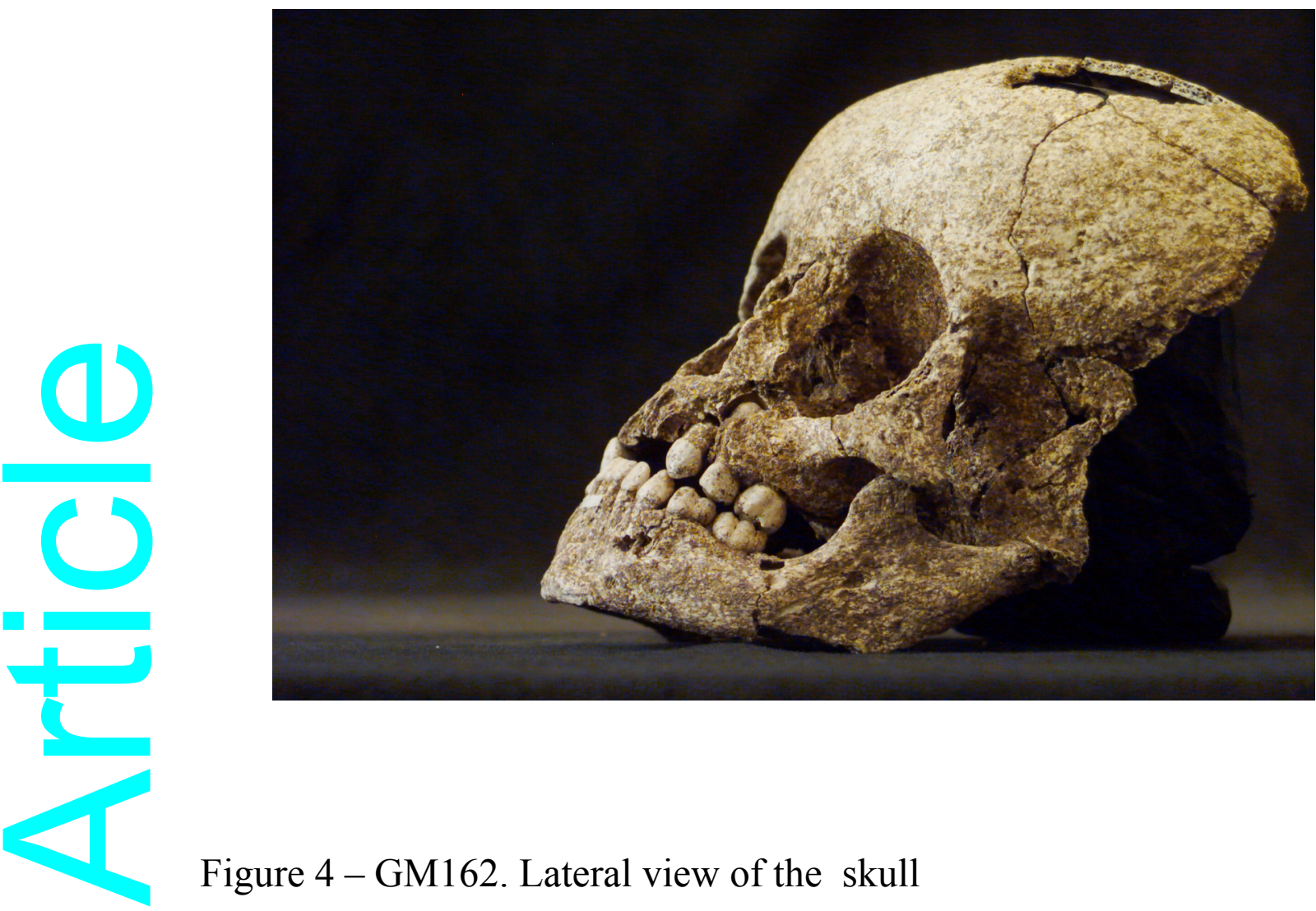

Figure 4-GM162. Lateral view of the skull

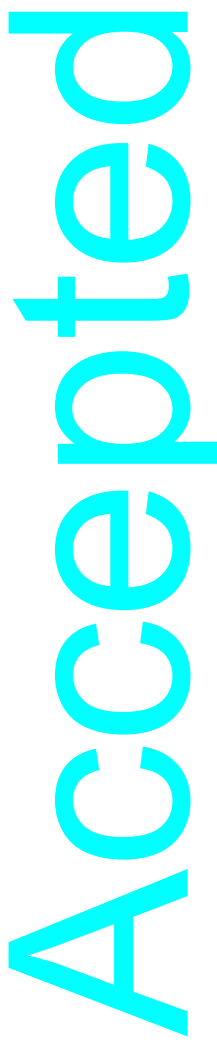




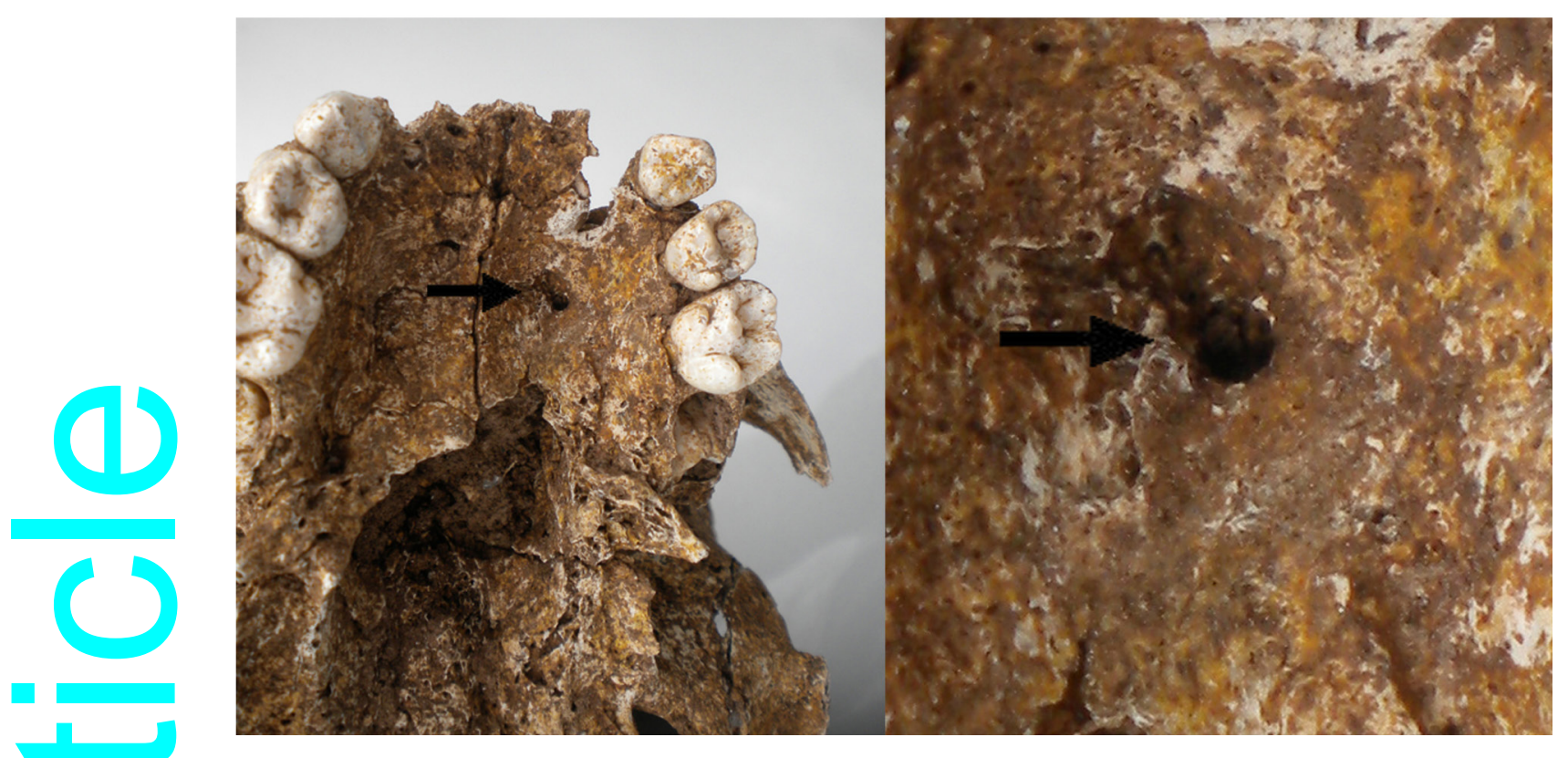

Figure 5 - GM162. Palatal view. Subcircular perforation of the hard palate

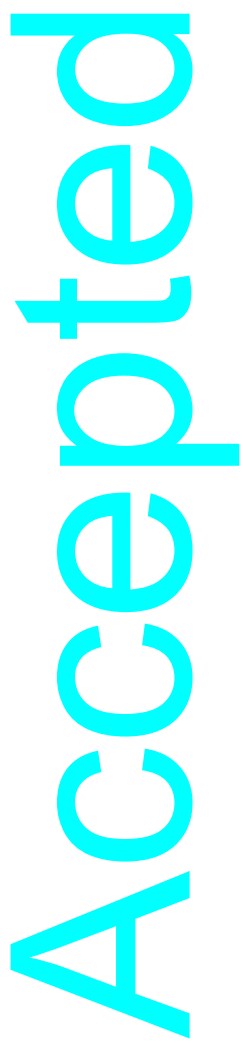




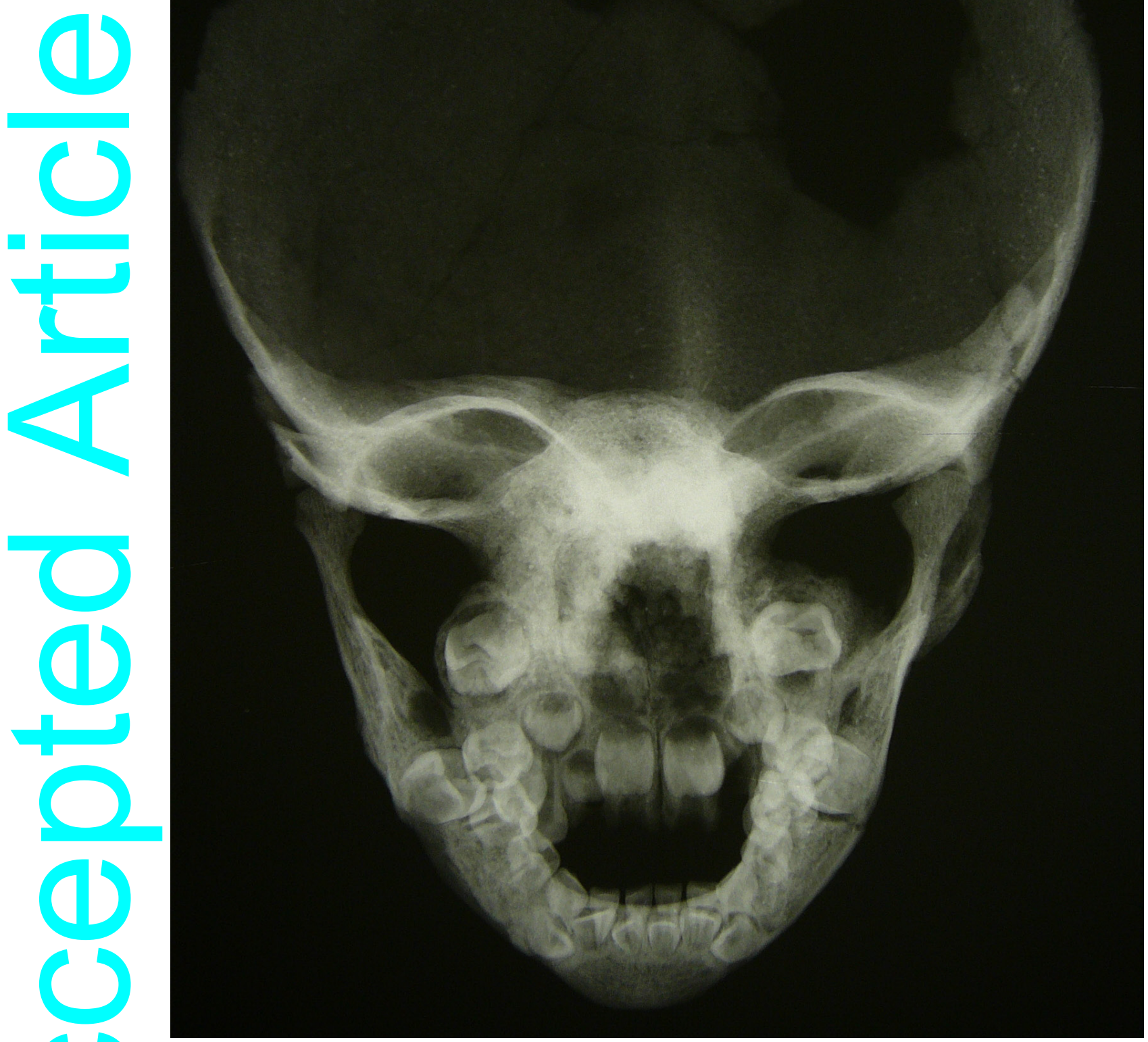

Figure 6-GM162. X-ray in frontal view. 


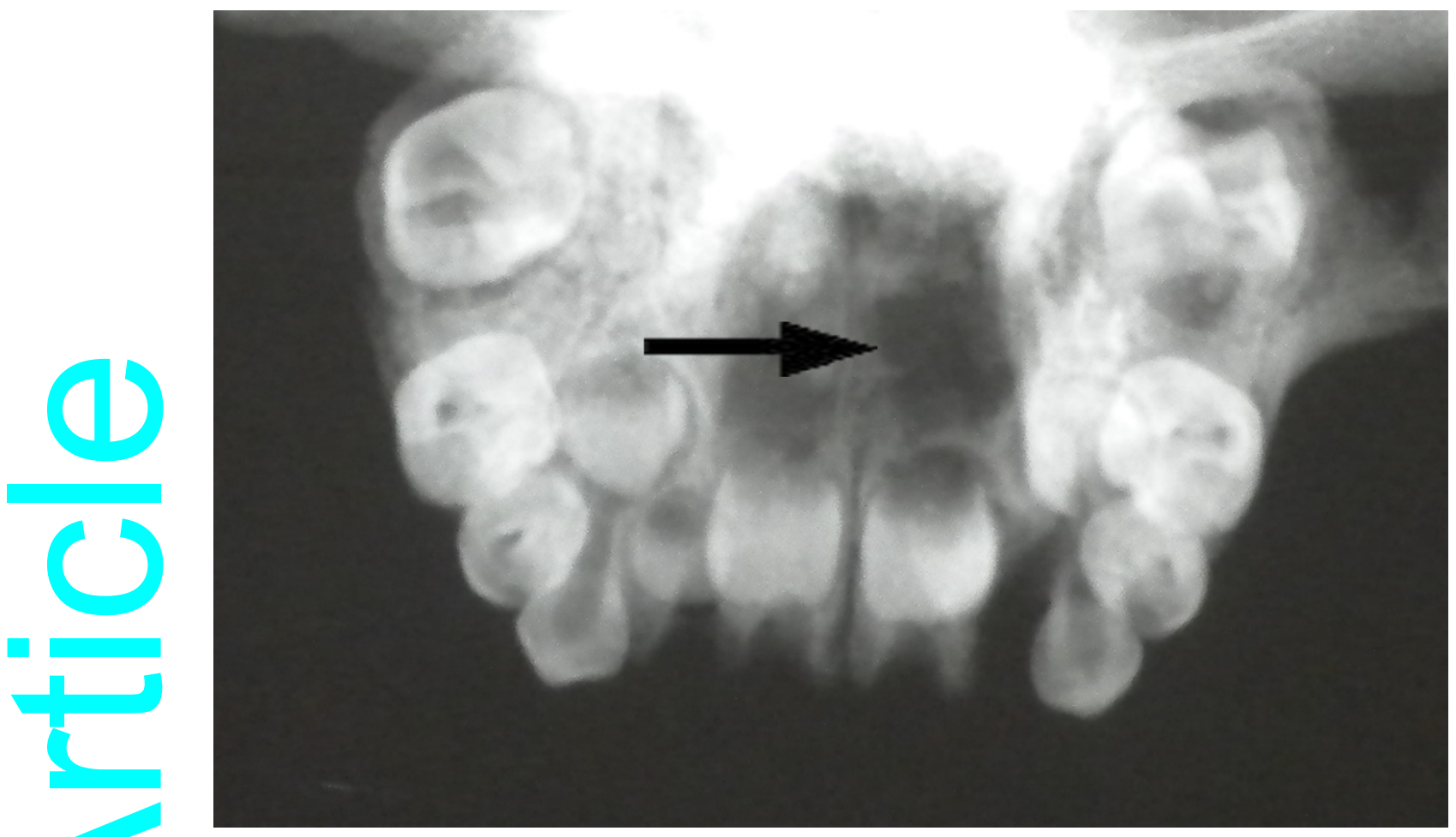

Figure 7- GM162. X-ray in palatal view. The black arrow shows the perforation on the hard palate 


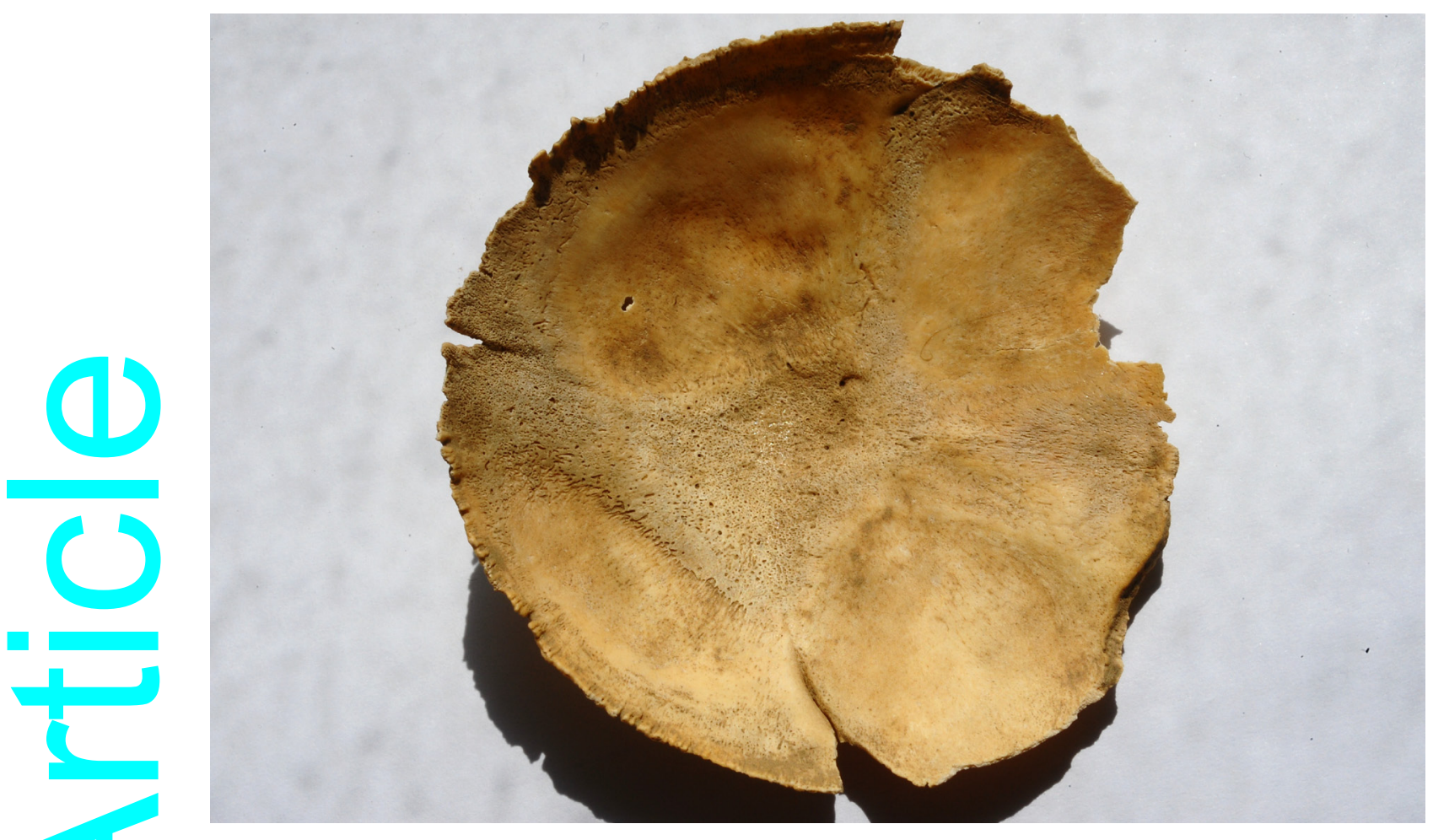

Figure 8 - SK9/1. Inner view of the occipital of the Kovuklukaya child

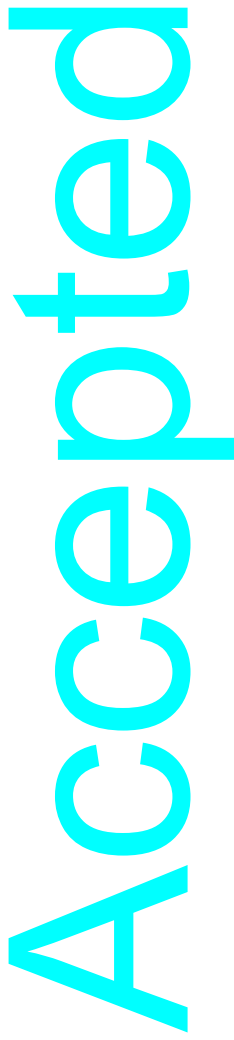




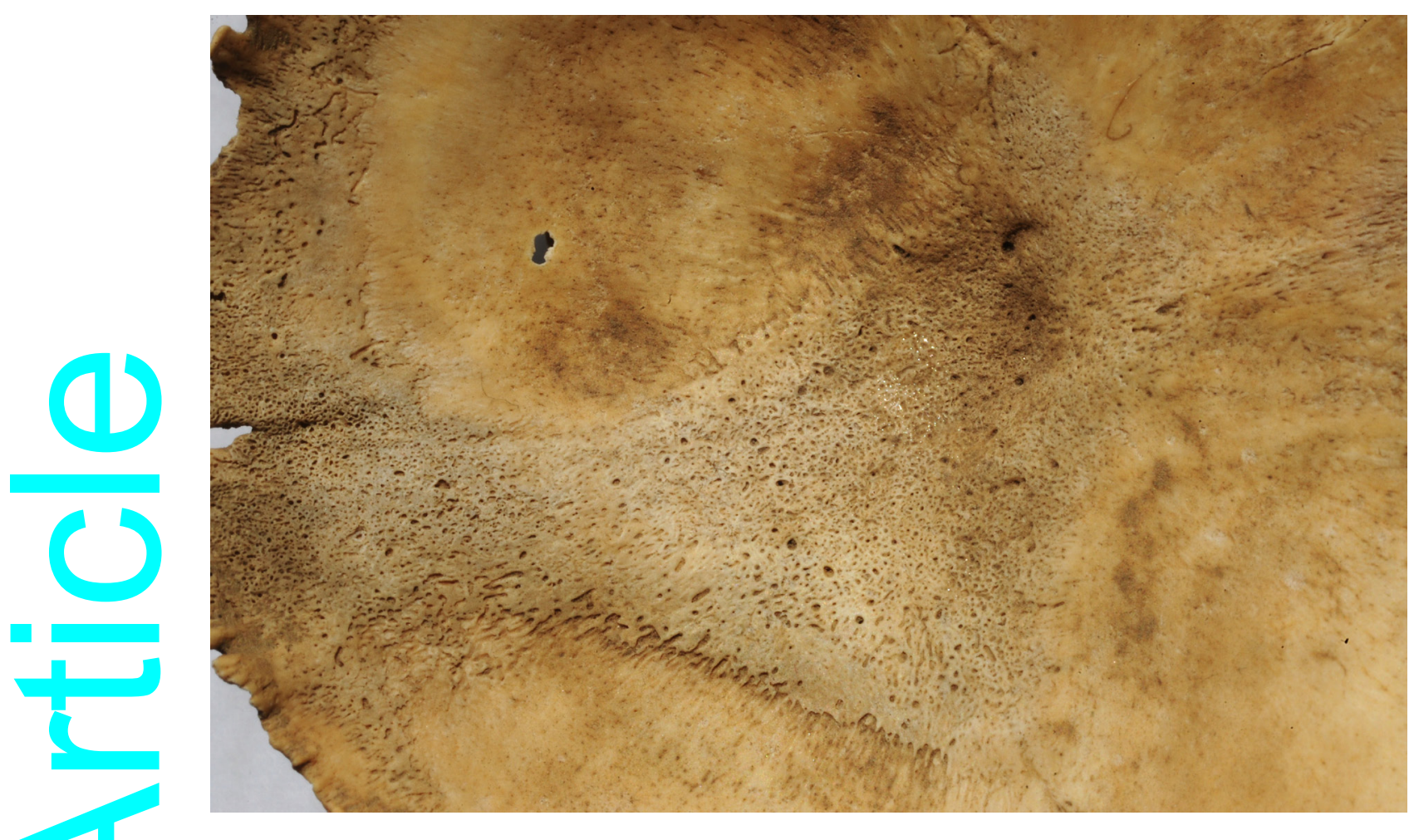

Figure 9 - SK9/1. Details of the changes viewed from the cribrotic aspect of the lesions 


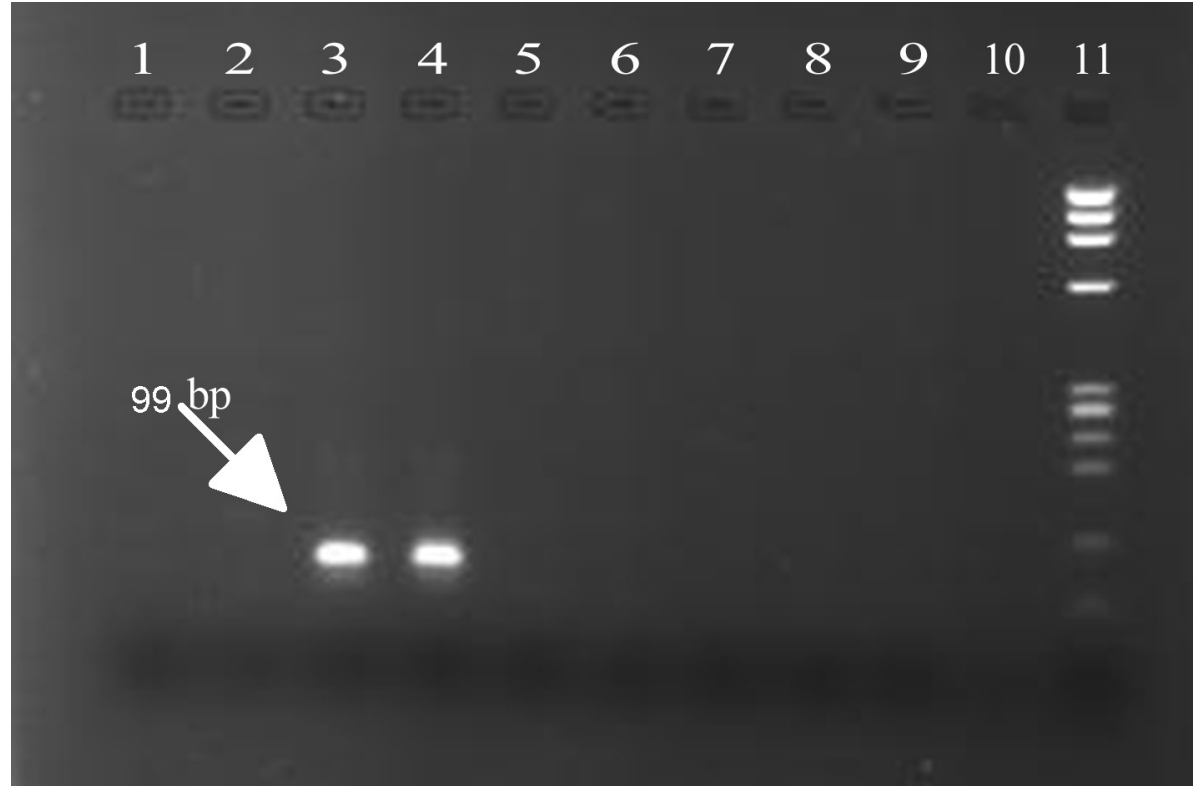

Figure 10 - Gel electrophoresis demonstrating a 99-bp RLEP sequence specific for M. leprae, from the specimen shown in figures 8 and 9 (lane 3 ), and from nasal scrapings of an adult male SK11/2 with typical palaeopathology of multibacillary leprosy from the same archaeological site (lane 4). Lanes 1, 2 and 5-8: other samples (negative); lane 9: negative DNA extraction control; lane 10: negative PCR control; lane 11: PhiX174HaeIII molecular markers 